\title{
INFLUENCE OF HALOGEN IONS ON PHYSICAL PROPERTIES OF SOME BORO-VANADATE GLASSES
}

\author{
A. M. Abdel-Ghany \\ Basic Science Department, Faculty of Engineering Science, Sinai University, El-Arish, Egypt. \\ E-mail address: aabdelghany83@yahoo.com, Tel: +201015859366
}

\begin{abstract}
Some sodium boro-vanadate glasses containing various halogen ions (chlorine, bromine or iodine) were prepared by melting at $1000^{\circ} \mathrm{C}$ for $2 \mathrm{hrs}$ and annealed at $300^{\circ} \mathrm{C}$ for $3 \mathrm{hrs}$. These glasses were characterized by measuring the experimental densities, $d c$ conductivities and volume-magnetic susceptibilities. Then the empirical densities, experimental and empirical molar volume values, electrical activation energies, mass- and molar-magnetic susceptibilities as well as the total mass attenuation coefficients of all glasses were calculated.

It was found that, the activation energy decreased as the halogen content was increased which may be due to the increase in the mobility of sodium ions and the gradual formation of some terminal non-bridging halogens, in addition to the electron hopping process between different oxidation states of vanadium. It decreased also ongoing from chlorine to iodine that can be ascribed to the differences in ionic radii of halogen ions. Also, the decrease in activation energy may be due to the increase in the interstitial vacancies. This was confirmed by the density and the molar volume results.

It was supposed that the increase in the paramagnetic character of the studied glasses with the increase of halogen content may be due to the formation of $\mathrm{VXO}_{3}$ groups. Also, the magnetic properties were found to decrease as the ionic radius of the introduced halogen ions increased. This can be attributed to the increase in the internal vacancies through the network.

Correlations were established between the experimental values of both the activation energy and molar susceptibility with the calculated molar volume values of the studied glasses.

According to the results of the mass attenuation coefficients, it was found that, the sample contains 25 mol\% NaI is the best one that can be used as $\gamma$-ray attenuator, but only at gamma-ray energies up to $356 \mathrm{keV}$.
\end{abstract}

Keywords: Physical Properties of Glass, Glass Containing Halogen Ions, Magnetic Susceptibility of Glass and $\gamma$-Ray Attenuation Parameters.

\section{INTRODUCTION:}

Vanadium containing glasses have early attracted the attention of many workers, and hence many articles have been published dealing with the study of their structure and properties [1-6]. It is observed that special interest has been paid to the electronic transport properties of such glasses due to their interesting applications in the field of electronic devices [4-8]. It was found that vanadium ions occupy $\mathrm{V}^{5+}, \mathrm{V}^{4+}$ and/or $\mathrm{V}^{3+}$ in the network of various oxide glasses [7]. Mott had early concluded that the electronic conduction in vanadium oxide containing glass may follow the phonon assistance of electron hopping between different localized states (small polaron hopping) [9]. If some alkali oxides are introduced into such glasses, ionic conduction is also present, and the electrical conductivity of such glass is markedly increased as the alkali oxide content was increased $[10,11]$.

From another point of view, it was found that, only few studies on the structure and properties of oxide glasses containing halogen ions have been also performed. From these studies, it was found that halogen ions increase the electrical conductivity and decrease the activation energy, and the gradual increase of halogen ions show very slight increase in the magnetic susceptibility values of glasses, [1216].

On the other hand, glasses containing heavy metal ions (HMIs) are also of special interest due to their important applications, especially in the field of ionizing radiation protection [17-20]. In spite of the published articles in these fields, the problem still needs more investigation. 
Therefore, in this article, the influence of the gradual replacement of oxygen by halogen ions (chlorine $(\mathrm{Cl})$, bromine $(\mathrm{Br})$ or iodine $(I)$ ) on the dc electrical conductivity, electrical activation energy, density and molar volume as well as the magnetic susceptibility of some sodium-boro-vanadate glasses will be thoroughly studied. The mass attenuation coefficients were also calculated to chick the suitability of these glasses to act as gamma-ray attenuators. Also, it was tried to correlate the experimentally obtained molar volume values with both the activation energy and the molar magnetic susceptibility values of all the studied glasses.

\section{EXPERIMENTAL WORK:}

Some sodium boro-vanadate glasses of the following composition, [50 mol\% $\quad \mathrm{B}_{2} \mathrm{O}_{3^{-}}-25$ mol\% $\mathrm{V}_{2} \mathrm{O}_{5^{-}}(25-\mathrm{Y}) \mathrm{mol} \% \mathrm{Na}_{2} \mathrm{O}-\mathrm{Y}$ mol\% $\mathrm{NaX}$ (where, $\mathrm{Y}$ takes the values $0,5,10,15,20$ and $25 \mathrm{~mol} \%$, where $\mathrm{X}$ represents the introduced halogen ion (chlorine $(\mathrm{Cl})$, bromine $(\mathrm{Br})$ and iodine $(I)$ ). Pure grade chemicals were used as raw materials for preparing the supposed glasses and the batches were melted in porcelain crucibles in an electrically heated furnace at $1000{ }^{\circ} \mathrm{C}$ for $2 \mathrm{hrs}$. The melts were stirred several times during melting to ensure complete mixing and homogeneity. Melts were then casted on a preheated stainless steel plate and after just sitting they were directly transferred to the annealing furnace at $300^{\circ} \mathrm{C}$ for $3 \mathrm{hrs}$. The furnace was then turned off and was left to cool to room temperature (RT) with a cooling rate of about $1^{\circ} \mathrm{C} / 3$ minutes.

Archimedes technique was applied to obtain the experimental density values of the studied glasses using xylene as an immersing liquid of stable density value at RT [0.86 $\left.\mathrm{gm} / \mathrm{cm}^{3}\right]$. The empirical densities as well as the experimental and empirical molar volume values were also calculated, since the comparison between the empirical and experimental values of both density and molar volume can be used to confirm the amorphous nature of the studied glasses [21].
For dc electrical conductivity measurements, the solid glasses were polished to obtain disks of $8 \mathrm{~mm}$ diameter and $2 \mathrm{~mm}$ thickness, and both sides were painted by silver paste to ensure complete electrical contact. A $610 \mathrm{C}$ keithley electrometer and a DTC2 Oxford temperature stabilizer were used to measure the electrical conduction through a glass sample. The measurements were carried out in the temperature range from 300 up to $600 \mathrm{~K}$. The electrical activation energies were then calculated using Arrhenius equation [8].

For magnetic susceptibility measurements, pieces of the solid samples were powdered to obtain particle size less than 200 mesh size. Gouy method (an Oxford apparatus) outfitted with one tesla electromagnet was used to obtain the volume susceptibility values. The mass- and molar- magnetic susceptibilities were then calculated [22].

It is also of interest to calculate the mass attenuation coefficients of the studied glasses, since they contain bromine or iodine anions, where these ions may also attenuate some ionizing radiations. However, the total mass attenuation coefficients $\left(\mu_{m}\right)$ will be now calculated by applying WIN-XCOM program based on the mixture rule [23].

\section{RESULTS AND DISCUSSION:}

Three glass systems have been prepared, in which $\mathrm{Na}_{2} \mathrm{O}$ was gradually replaced by $\mathrm{NaX}$ ( $\mathrm{mol} / \mathrm{mol}$ ) in proportions of 5 moles (where $X$ represents $\mathrm{Cl}$ in the first system, $\mathrm{Br}$ in the second system and $I$ in the third system). The prepared solid glasses were then investigated by the following experimental measurements and empirical calculations.

\subsection{Density and Molar Volume:}

Density of amorphous and crystalline solids is property of importance, since the density values are needed to calculate the molar volume values and the mass- and molarmagnetic susceptibilities, as well as some attenuation parameters. Therefore, $\rho_{\exp }$ was 
firstly measured by applying Archimedes method and using equation (1),

$$
\rho_{\exp }=\rho_{l}\left[M_{a} / M_{a}-M_{l}\right]
$$

where, $M_{a} \& M_{l}$ are the weights of a sample in air and liquid respectively, and $\rho_{l}$ is the density of the emersion liquid.

The experimental molar volume values $\left(V_{m}\right)_{\exp }$ were then calculated using equation (2),

$$
\left(V_{m}\right)_{\exp }=M_{m} / \rho_{\text {exp }}
$$

where $M_{m}$ is the main molecular weight in $(\mathrm{g} / \mathrm{mol})$ of a glass sample and $\rho_{\text {exp }}$ is its density.

The empirical density values $\left(\rho_{\text {emp }}\right)$ were also calculated using the following relation [24],

$$
\rho_{\mathrm{e} m \mathrm{p}}=\sum_{i} \rho_{i} X_{i}
$$

where $\rho_{i}$ are the densities of the oxides forming a glass sample and $X_{i}$ are the mole fraction of each oxide.

The empirical molar volume $\left(V_{m}\right)_{e m p}$ values were then calculated using equation (2) also, but with replacing $\rho_{\text {exp }}$ by $\rho_{\text {emp }}$ [24].

All the obtained values are exhibited in Table (1).

\begin{tabular}{|c|c|c|c|c|c|c|c|}
\hline \multicolumn{2}{|c|}{$\mathrm{NaX} \mathrm{mol} \%$} & 0 & 5 & 10 & 15 & 20 & 25 \\
\hline \multirow{3}{*}{$\begin{array}{c}\rho_{\text {exp. }} \\
\left(\mathrm{g} / \mathrm{cm}^{3}\right)\end{array}$} & I & 2.45 & 2.37 & .28 & 23 & 2.17 & 2.13 \\
\hline & $\mathrm{Br}$ & 2.45 & 2.39 & 2.33 & 2.27 & 2.23 & 2.18 \\
\hline & $\mathrm{Cl}$ & 2.45 & 2.41 & 2.37 & 2.33 & 2.29 & 2.25 \\
\hline \multirow{3}{*}{$\begin{array}{c}\rho_{\text {emp. }} \\
\left(\mathrm{g} / \mathrm{cm}^{3}\right)\end{array}$} & I & 3.06 & 3.13 & 3.20 & 3.27 & 3.34 & 3.41 \\
\hline & $\mathrm{Br}$ & 3.06 & 3.11 & 3.15 & 3.20 & 3.25 & 3.30 \\
\hline & $\mathrm{Cl}$ & 3.06 & 3.05 & 3.05 & 3.04 & 3.04 & 3.03 \\
\hline \multirow{3}{*}{$\begin{array}{c}V_{\text {m exp. }} \\
\left(\mathrm{cm}^{3} / \text { mole }\right)\end{array}$} & I & 39.09 & 42.26 & 45.85 & 48.85 & 52.22 & 55.26 \\
\hline & $\mathrm{Br}$ & 39.09 & 40.93 & 42.86 & 44.90 & 46.62 & 48.63 \\
\hline & $\mathrm{Cl}$ & 39.09 & 39.67 & 40.26 & 40.88 & 41.51 & 42.17 \\
\hline \multirow{3}{*}{$\begin{array}{c}V_{\mathrm{m} \text { emp. }} \\
\left(\mathrm{cm}^{3} / \text { mole }\right)\end{array}$} & I & 31.30 & 32.00 & 32.67 & 33.31 & 33.93 & 34.52 \\
\hline & $\mathrm{Br}$ & 31.30 & 31.48 & 31.66 & 31.84 & 32.01 & 32.17 \\
\hline & $\mathrm{Cl}$ & 31.30 & 31.29 & 31.29 & 31.29 & 31.28 & 31.28 \\
\hline
\end{tabular}

Table (1): The obtained experimental and empirical density and molar volume values.

Inspecting the obtained density and molar volume values in Table (1) and comparing their experimental and empirical values, it appeared that the empirical density values are usually higher than those obtained experimentally. On the other hand, it appeared also that the empirical molar volume values are usually lower than those obtained experimentally. These comparisons indicate that, all samples are characterized by their randomness nature. Therefore, it can be stated that all the studied glasses are in pure amorphous glassy phase [23].

Figure (1), shows the change of the obtained density values, while Figure (2) represents the variations of the calculated molar volume values as a function of halogen content. It appeared that, the density value of the base glass (halogen free sample) is found to be equal $2.45 \mathrm{gm} / \mathrm{cm}^{3}$. As halogen ions starts to enter the glass network, a considerable decrease is observed, and more increase of halogens replacing oxygen ions makes the density values of all glass systems decreased approximately linearly. It is found that the glasses that contain chlorine ions represent the highest density values, while the glasses that contain iodine ions represent the smallest density values. On the other hand, the molar volume values represent a linear increase with the increase of halogen ions. It is also shown that the glass system that contains chlorine ions exhibits the smallest molar volume values, but the system which contains iodine ions represents the largest molar volume values.

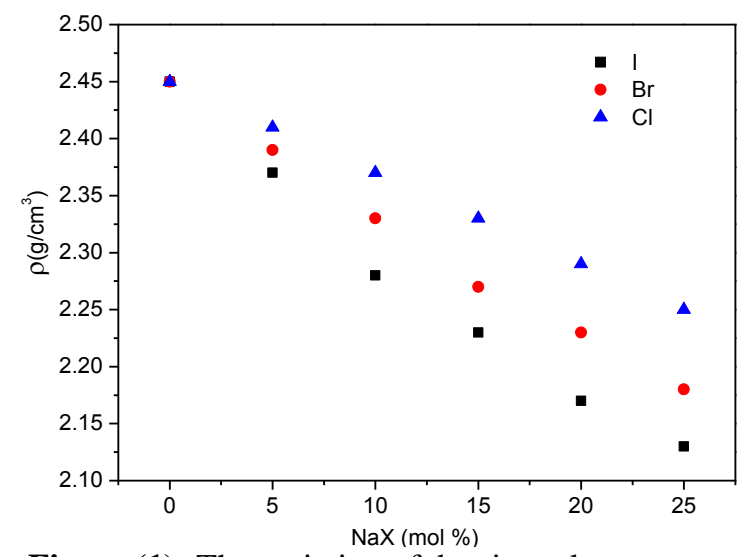

Figure (1): The variation of density values versus $\mathrm{NaX}$ content.

The observed decrease in density indicated that the glass networks become open and the 
internal free volume increased gradually with the gradual increase of halogen content. This was confirmed by the gradual increase of the

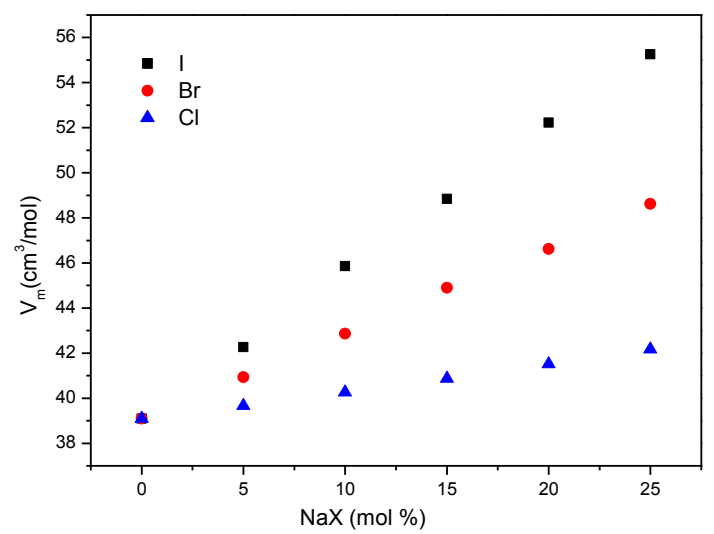

Figure (2): The variation of molar volume values versus $\mathrm{NaX}$ content.

molar volume values of all the studied glass systems. The higher density values of the glass system containing $\mathrm{Cl}$, in comparison with the glass system containing $I$, may be due to the larger ionic radius of $I$ ion in composition to both $\mathrm{Br}$ and $\mathrm{Cl}$ ions. This implies higher free volume in the system containing $I$ than both other systems. That is, it can be supposed that, the internal free volume in all system takes the order, the glass system containing $I>$ that containing $\mathrm{Br}>$ that containing $\mathrm{Cl}$.

In spite of the above suppositions and discussion, a question is floated now on the surface, which is, what about the variation of the number of ion densities of all the composing elements?. However the number of ion densities were then calculated applying equation (4),

$$
N=a\left[N_{A} \rho_{\exp } X_{i} / M_{w}\right]
$$

where $a$ is the number of formula ions, $\rho_{\exp }$ is the experimental density of a glass sample, $X_{i}$ is the weight fraction of an elements in each sample, $M_{w}$ is the molecular weight of such glass samples and $N_{A}$ is Avogadro number. The obtained values are presented in Table (2), for all the studied glass systems.

It is appeared from Table (2) that, the number of ion density of $\mathrm{B}, \mathrm{V}, \mathrm{Na}$ and $\mathrm{O}$ decreased gradually when $\mathrm{Na}_{2} \mathrm{O}$ was gradually replaced by $\mathrm{NaX}$, while that of halogens increased. The observed decrease of $\mathrm{Na}$ and $\mathrm{O}$ as well as the increase of halogen are logically accepted, but the decrease of $B$ and $V$ ions can be attributed to the gradual increase of the molar volume values which is due to the increase of $\mathrm{NaX}$ content [13].

Table (2): The number of ion densities of all elements in all the studied glasses.

\begin{tabular}{|c|c|c|c|c|c|c|c|}
\hline \multicolumn{2}{|c|}{$\mathrm{NaX} \mathrm{mol} \%$} & 0 & 5 & 10 & 15 & 20 & 25 \\
\hline \multirow{3}{*}{$\begin{array}{l}\mathrm{N}(\mathrm{B}) 10^{21} \\
\left(\mathrm{~cm}^{-3}\right)\end{array}$} & I & 15.4 & 14.2 & 13.1 & 12.3 & 11.5 & 10.9 \\
\hline & $\overline{\mathrm{Br}}$ & 15.4 & 14.7 & 14.1 & 13.4 & 12.9 & 12.4 \\
\hline & $\mathrm{Cl}$ & 15.4 & 15.2 & $\overline{15.0}$ & 14.7 & 14.5 & 14.3 \\
\hline \multirow{3}{*}{$\begin{array}{c}\mathrm{N}(\mathrm{V}) 10^{21} \\
\left(\mathrm{~cm}^{-3}\right)\end{array}$} & $\mathrm{I}$ & 7.7 & 7.1 & 6.6 & 6.2 & 5.8 & 5.4 \\
\hline & $\mathrm{Br}$ & 7.7 & 7.4 & 7.0 & 6.7 & 6.5 & 6.2 \\
\hline & $\mathrm{Cl}$ & 7.7 & 7.6 & 7.5 & 7.4 & 7.3 & 7.1 \\
\hline \multirow{3}{*}{$\begin{array}{c}\mathrm{N}(\mathrm{Na}) 10^{21} \\
\left(\mathrm{~cm}^{-3}\right)\end{array}$} & I & 7.7 & 6.4 & 5.3 & 4.3 & 3.5 & 2.7 \\
\hline & $\overline{\mathrm{Br}}$ & 7.7 & 6.6 & 5.6 & 4.7 & 3.9 & 3.1 \\
\hline & $\mathrm{Cl}$ & 7.7 & 6.8 & 6.0 & 5.2 & 4.4 & 3.6 \\
\hline \multirow{3}{*}{$\begin{array}{l}\mathrm{N}(\mathrm{X}) 10^{21} \\
\left(\mathrm{~cm}^{-3}\right)\end{array}$} & I & 0.0 & 0.7 & 1.3 & 1.8 & 2.3 & 2.7 \\
\hline & $\mathrm{Br}$ & 0.0 & 0.7 & 1.4 & 2.0 & 2.6 & 3.1 \\
\hline & $\mathrm{Cl}$ & 0.0 & 0.8 & 1.5 & 2.2 & 2.9 & 3.6 \\
\hline \multirow{3}{*}{$\begin{array}{l}\mathrm{N}(\mathrm{O}) 10^{21} \\
\left(\mathrm{~cm}^{-3}\right)\end{array}$} & I & 46.2 & 42.7 & 39.4 & 37.0 & 34.6 & 32.7 \\
\hline & $\overline{\mathrm{Br}}$ & 46.2 & 44.1 & $\overline{42.2}$ & 40.2 & 38.8 & 37.2 \\
\hline & $\mathrm{Cl}$ & 46.2 & 45.5 & 44.9 & 44.2 & 43.5 & 42.8 \\
\hline
\end{tabular}

\subsection{Conductivity and Activation Energy}

The dc electrical conductivity has been measured in the temperature range from 300 to $600 \mathrm{~K}$. The electrical conductivity values of all these glasses were obtained at different fixed temperatures. The calculated values of $[\ln (T \sigma)]$ were plotted as a function of the reciprocal of the absolute temperatures and Figure (3), shows such relations for the glass samples which contain $15 \mathrm{~mol} \% \mathrm{NaX}$ (X represents $\mathrm{Cl}, \mathrm{Br}$ or I). The electrical conductivities of all glasses show an increase as the temperature was gradually elevated.

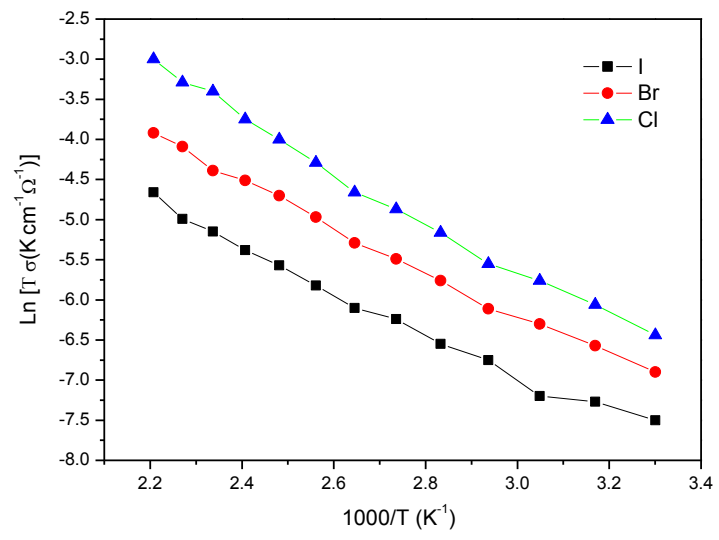

Figure (3): The variation of $\ln (T \sigma)$ versus $1000 / T$ for the glass samples containing $15 \mathrm{~mol} \% \mathrm{NaX}$, as representative figure. 
The activation energies were then calculated for all the studied glasses by applying Arrhenius equation (equation no. 5),

$$
\sigma=\left(\sigma_{o} / T\right) \exp (-\mathrm{W} / \mathrm{kT})
$$

where $\sigma$ is the electrical conductivity of a sample, $\sigma_{0}$ is pre-exponential factor, $k$ is Boltzmann constant, $T$ is the absolute temperature and $W$ is the activation energy.

The activation energy of conduction for the investigated glasses show a decrease as the sodium halide content is gradually increased as shown in Figure (4).

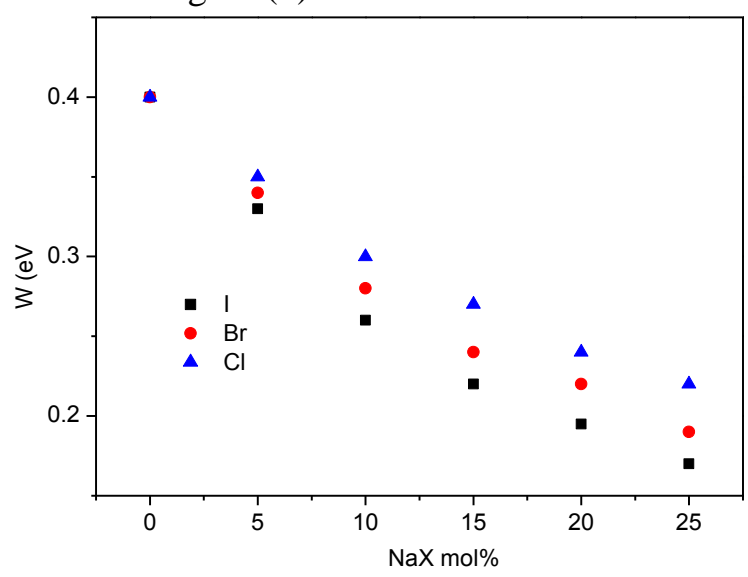

Figure (4): The variation of the activation energy values versus $\mathrm{NaX}$ content.

It is seen that the glass system containing sodium iodide represents the lowest activation energy values, while the glass system that containing sodium chloride represents the highest activation energy values. These results are found to be in agreement with the change in the density and molar volume values.

It is supposed that the gradual replacement of oxygen ions by various halogen ions in these glasses setup vacancies with different volumes due to the differences of their ionic radii. The halogens may act also as substitutional impurities in these glasses. Accordingly, it can be supposed that, the electrical conduction in these glass systems may be due to the following factors: (a) The mobility of the positively charged sodium cations throughout the glass network [11].

(b) The electron hopping between the localized states set forth by different oxidation states of vanadium cations [8].

(c) The present negatively charged halogens, which act as interstitial impurities and/or as terminal non-bridging halogen ions, as well as their effect of changing the volumes of the interstitial vacancies in the glass-network [25].

Since oxygen ions represent the smallest ionic radius in comparison with the used halogen ions, therefore vacancies of the smallest volume have be formed in the base glass. Hence, the mobility of the positively charged sodium cations appeared in its lowest state [26]. But, it is known that the ionic radius of chlorine is of the smallest value when compared with those of the other used halogens, therefore the glass samples which contain chlorine ions, show the highest activation energies with respect to the other glass systems. The lowest activation energy values are represented by glasses containing iodine ions because this ion have the largest ionic radius and consequently imposes the largest vacancies in the glass network.

The addition of halogen ions act to form terminal borate and / or terminal vanadate groups of the form $\left[\mathrm{VO}_{3}-\mathrm{X}\right.$ and / or $\left.\mathrm{BO}_{2}-\mathrm{X}\right]$. The presence of such dangling and nonbridging halogen in addition to the larger volume of halogen ions (in comparison to oxygen) produces more open glass network structure [25]. This may support the suggestion that the increase of sodium halides increase the ionic conductivity which may be due to the increase of the mobility of sodium ions [27]. Also, the increase in the conductivity with increasing halogen ions may be due to the fact that $\mathrm{Na}-\mathrm{X}$ bond strength is weaker than that of $\mathrm{Na}-\mathrm{O}$ bond [25].

The calculated activation energies for the glasses containing the same concentrations of 
various halogen ions are found to decrease gradually ongoing from glasses containing chlorine to glasses containing iodine ions. Such decrease in the activation energy with the mentioned order is found in complete agreement with the increase of the ionic radii of the introduced halogen ions. In addition to this, since the field strength of the halogen ions takes the order $\mathrm{Cl}>\mathrm{Br}>\mathrm{I}$, this makes the strength of the B-X and / or V-X bonds, follow also the same order [25].

The increase in the volume of the individual vacancies ongoing from glasses containing chlorine ions to glasses containing iodine ions, can be confirmed from the results of densities and molar volume values of these glasses.

\subsection{Volume-, Mass- and Molar- Magnetic Susceptibilities}

The magnetic properties of glasses are of special interest, and therefore Gouy method was used here to measure the volume magnetic susceptibility $(k)$ of the studied glasses, by using equation (6),

$$
k=2 g \Delta m / A H^{2}
$$

where $g$ is the acceleration due to gravity, $\Delta m$ is the change in the mass with the square value of the applied magnetic field intensity $\left(H^{2}\right)$ and $A$ is the cross sectional area of the used tube, respectively.

The mass magnetic susceptibility $(M)$ and the molar magnetic susceptibility $(\phi)$ were also calculated by applying equations (7) \& (8) respectively,

$$
\begin{aligned}
& M=k / \rho_{\text {exp. }} . \\
& \phi=k V_{m \exp }
\end{aligned}
$$

All the obtained volume-, mass- and molarmagnetic susceptibility are listed in Table (3).

Figure (5) shows the variation of the molar magnetic susceptibility values as a function of halogen ions content, in all the studied glass systems. It appears that the molar magnetic properties increased gradually with the gradual increase of $\mathrm{NaX}$ content as well as ongoing from glasses containing chlorine to glasses containing iodine ions.

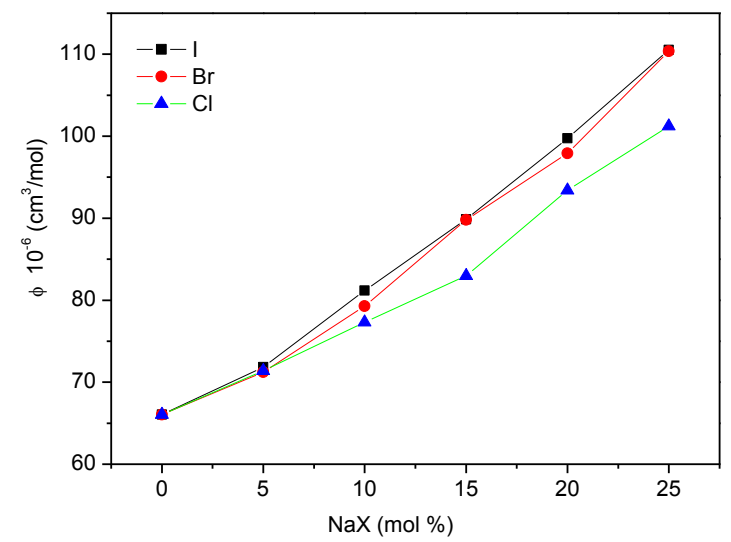

Figure (5): The molar magnetic susceptibility values versus $\mathrm{NaX}$ content.

Considering the prepared base glass composition, it is supposed that boron cations form $\mathrm{BO}_{3}$ groups while vanadium cations form $\mathrm{VO}_{3}, \mathrm{VO}_{4}$ and $\mathrm{VO}_{5}$ groups, that is, both cations act as network formers in these glasses. The addition of halogens replacing oxygen ions form some terminated halogens, with the

\begin{tabular}{|c|c|c|c|c|c|c|c|c|c|}
\hline \multirow{2}{*}{$\begin{array}{c}\mathrm{Nax} \\
\mathrm{mol} \% \\
\end{array}$} & \multicolumn{3}{|c|}{$k 10^{-6}$} & \multicolumn{3}{|c|}{$M 10^{-6}\left(\mathrm{~cm}^{3} / \mathrm{g}\right)$} & \multicolumn{3}{|c|}{$\phi 10^{-6}\left(\mathrm{~cm}^{3} / \mathrm{mol}\right)$} \\
\hline & I & $\mathrm{Br}$ & $\mathrm{Cl}$ & I & $\mathrm{Br}$ & $\mathrm{Cl}$ & I & $\mathrm{Br}$ & $\mathrm{Cl}$ \\
\hline 0 & 1.69 & 1.69 & 1.69 & 0.69 & 0.69 & 0.69 & 66.07 & 66.07 & 66.07 \\
\hline 5 & 1.70 & 1.74 & 1.80 & 0.72 & 0.73 & 0.75 & 71.85 & 71.22 & 71.40 \\
\hline 10 & 1.77 & 1.85 & 1.92 & 0.78 & 0.79 & 0.81 & 81.16 & 79.29 & 77.30 \\
\hline 15 & 1.84 & 2.00 & 2.03 & 0.83 & 0.88 & 0.87 & 89.88 & 89.79 & 82.98 \\
\hline 20 & 1.91 & 2.10 & 2.25 & 0.88 & 0.94 & 0.98 & 99.74 & 97.90 & 93.41 \\
\hline 25 & 2.00 & 2.27 & 2.40 & 0.94 & 1.04 & 1.07 & 110.52 & 110.38 & 101.22 \\
\hline
\end{tabular}
presented borate and vanadate groups. A

Table (3): The obtained magnetic susceptibility parameters for all the studied glasses. 
deficiency in the amount of oxygen ions will gradually takes place as the halogen ions increase in the glass network replacing oxygen ions. So, it is supposed that some $\mathrm{VXO}_{3}$ groups are formed instead of those $\mathrm{VO}_{4}$ that firstly formed. These groups are of higher paramagnetic properties due to the small cooperative interaction between the magnetic moments of the atoms forming such groups [26]. The increase of the molar magnetic susceptibility when going from glasses containing chlorine to glasses containing iodine ions, can be attributed to the increase in the magnetic interaction between the magnetic moments of the transition metal cations (V) and the surrounding oxygen and halogen ions. This may be due also to the gradual increase in the volumes of the internal vacancies that increase in the same sequence [26].

It is early confirmed that the physical properties of a glass is directly affected by any change in its composition and hence in its structure. It is usually stated that the dc conductivity increases when the glass structure becomes open [25], (due to an easier mobility of the charge carriers). However a relation between the molar volume and activation energy values are represented in Figure (6). From this Figure, it appears that the activation energy values show approximate linear decrease, and the decreasing rate differ from one glass to another. It was found that the glass system containing chlorine exhibits the highest decreasing rate, while the glass system containing iodine exhibits the lowest decreasing rate.

From another point of view, an attempt is also made to correlate the molar magnetic susceptibility with the molar volume values of these glasses as shows in Figure (7). From this Figure, the molar magnetic susceptibility values, for each glass system, show an increasing trend and the increasing rates differ from one glass system to another, depending on the type of the halogen ions. It is also appeared that, the highest increasing rate is exhibited by the glass system containing chlorine, while the lowest increasing rate is exhibited by the glass system containing iodine ions.

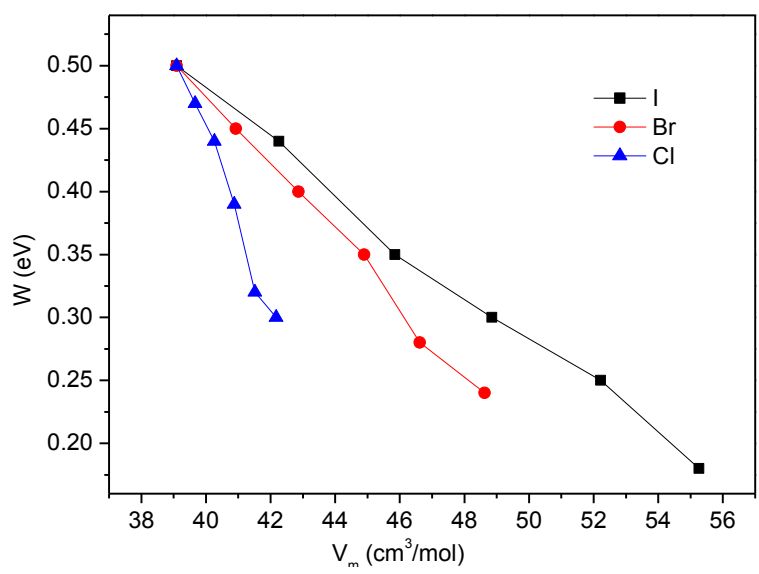

Figure (6): The change of $W$ versus $V_{m}$.

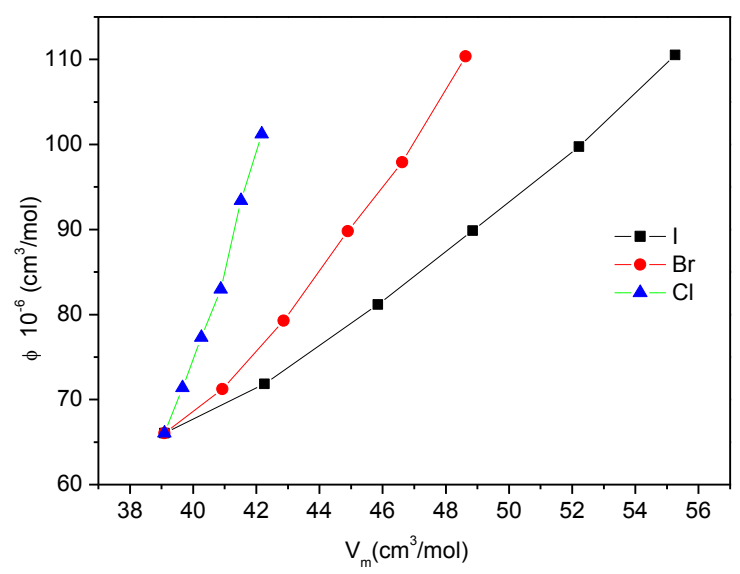

Figure (7): The change of the molar magnetic susceptibility versus $V_{m}$.

However, both these relations $\left(W \sim V_{m}\right.$ and $\phi \sim V_{m}$ ) can be now established, since these correlation were constructed from the obtained experimental data.

\subsection{Gamma-Ray Mass Attenuation Coefficient $\left(\mu_{m}\right)$ :}

It was established that glasses containing HMIs can be used now for ionizing radiation protection, since glasses are transparent to visible light as well as they are easy manufactured [23]. Since the studied glasses contain various amounts of halogen ions (especially $\mathrm{Br} \& I$ ions) therefore, the mass attenuation coefficients will be checked.

However, $\mu_{m}$ values were calculated by applying Win X-COM program, based on the mixture rule. The selected gamma-ray energies 
were $356,662,1173$ and $1332 \mathrm{keV}$, emitted from ${ }^{133} \mathrm{Ba}$ (for $356 \mathrm{keV}$ ), ${ }^{137} \mathrm{Cs}$ (for $662 \mathrm{keV}$ ) and ${ }^{60} \mathrm{Co}$ (for both $1173 \& 1332 \mathrm{keV}$ ) as low gamma-ray energies. The obtained values of $\mu_{m}$ are all then exhibited in Table (4). can be used as shielding material at low $\gamma$-ray energy and up to $356 \mathrm{keV}[17,23]$.

Table (4): The total mass attenuation coefficient $\left(\mu_{m}\right)$ values at different low $\gamma$-ray energies for all the studied glasses.

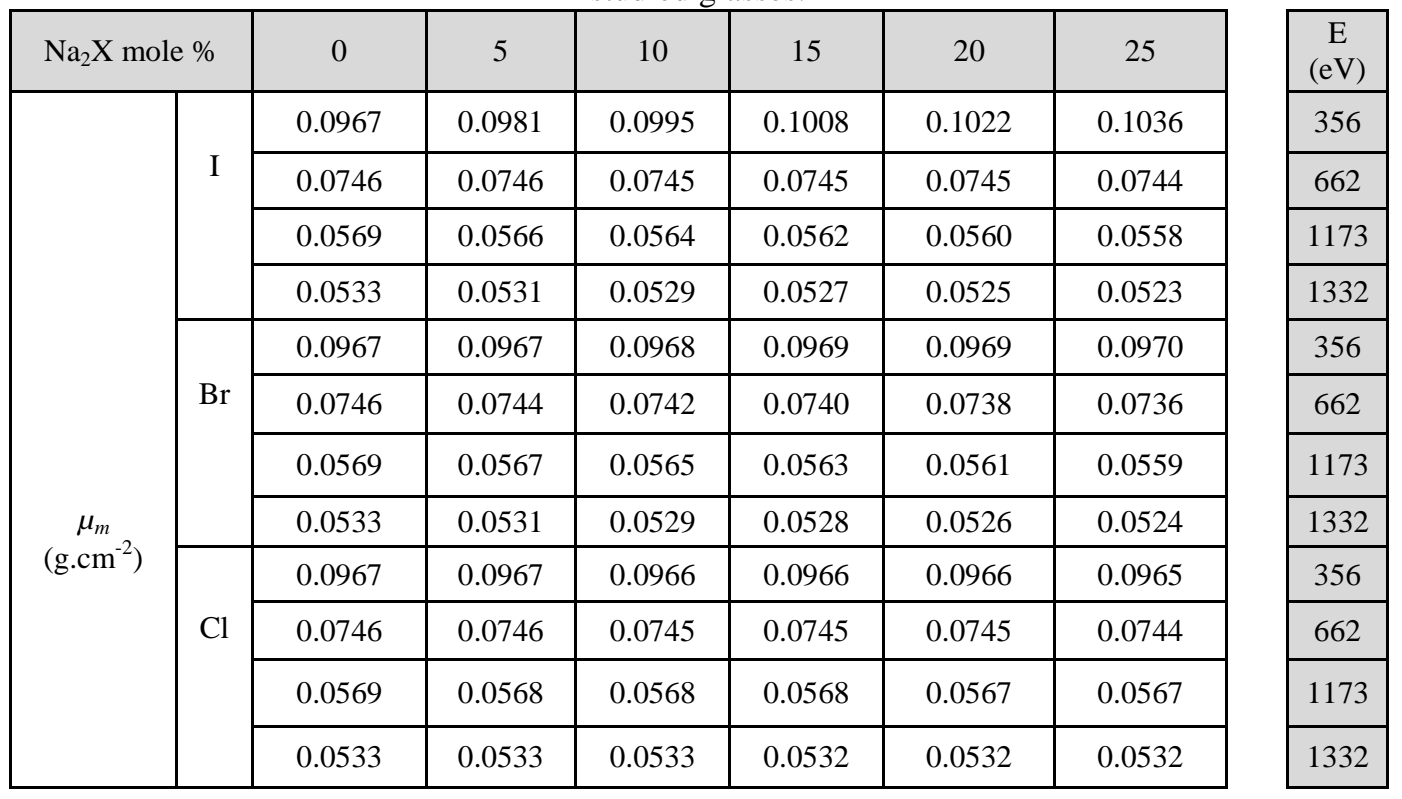

In order to clarify the suitability of the studied glasses to act as shielding material for $\gamma$-ray energy, the obtained values of $\mu_{m}$ are plotted in Fig. (8), as a function of $\mathrm{NaX}$ content, for all the applied $\gamma$-ray energies.

Inspecting the obtained values of $\mu_{m}$ that presented in Table (4), and represented graphically in Fig. (8), it is appeared generally that, $\mu_{m}$ increased slightly for glasses containing $\mathrm{I}$ and $\mathrm{Br}$ only at $356 \mathrm{keV} \gamma$-ray energy. At $662 \mathrm{keV}$ both the above glasses appeared approximately stable with the increase of $\mathrm{I}$ and $\mathrm{Br}$ content.

It appeared also that, $\mu_{m}$ of the glasses containing $C l$-at all $\gamma$-ray energies- and glasses containing $I$ and $\mathrm{Br}$ at $\gamma$-ray energies of 1173 and $1332 \mathrm{keV}$, decreases gradually with increasing halogen content.

According to the above obtained data, it can be stated that, the glass sample containing $25 \mathrm{~mol} \% \mathrm{NaI}$ represent the best sample that

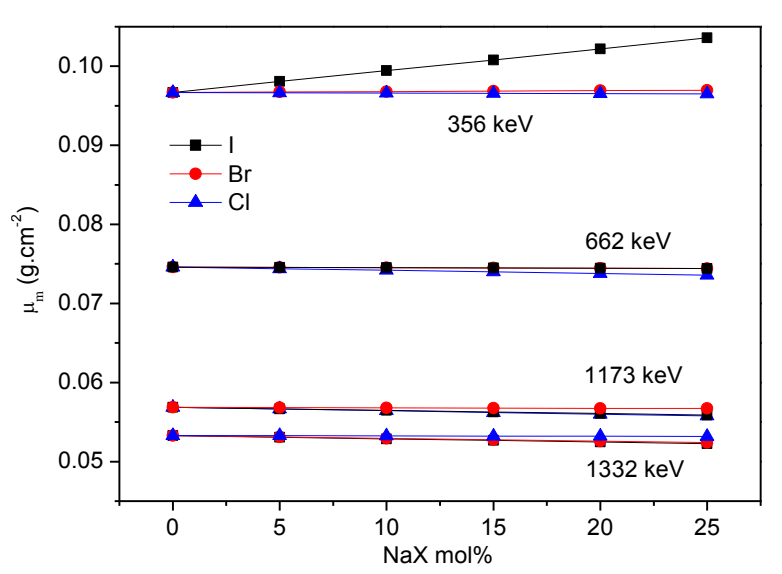

Fig. (8): The variation of $\mu_{m}$ at different low $\gamma$ ray energies versus $\mathrm{NaX}$ content, for all the studied glasses.

\section{CONCLUSION:}

According to the above investigations and the supposed discussion, it can be concluded that:

1- The gradual replacement of oxygen ions by halogen ions leads to a decrease of the activation energy values due to the formation of 
some $\mathrm{VO}_{3}-\mathrm{X}$ and/or $\mathrm{BO}_{2}-\mathrm{X}$ groups with a terminal non-bridging halogen.

2- These groups are found to be also of high paramagnetic properties.

3- The decrease of the activation energy values ongoing from glasses containing chlorine to glasses containing iodine ions may be due to the increase of the ionic radius of the introduced halogen, which may open the glass structure, and hence increases directly the internal vacancies in the glass network. This is confirmed directly by the density and molar volume values.

4- The increase of the internal vacancies increases directly the mobility of the charge carrying ions $\left(\mathrm{Na}^{+}\right.$ions).

5- A relation has been established between the molar magnetic susceptibility and the molar volume values of the studied glasses.

6- Another relation was also established between the electrical activation energy and the molar volume values of such glasses.

7- The calculated $\mu_{m}$ indicated that the glass sample containing $25 \mathrm{~mol} \% \mathrm{NaI}$ represent the best sample that can be used as shielding material but only at $356 \mathrm{keV} \gamma$-ray energy.

\section{REFERENCES:}

1. S. Prabakar, and K. J. Rao, London Proc. R. Soc., A 429, (1990), 1

2. Noboru Ichimose and Yuichrio Nakai, J. NonGyst. Solids, 203, (1996), 353.

3. O. Attos, M. Massot, M. Balkanski, E. HaroPoniatowski and M. Asonoza, J. Non-Cyst. Solids, 210, (1997), 163.

4._Meenakshi Pant, D. K. Kanchan, Poonam Sharma and Manish S. Jayswal, J. Mat. Sci. and Eng. (B), 149 (2008) 18.

5. E. R. Shaaban, M. Y. Hassaan, A. G. Mostafa and A. M. Abdel-Ghany, J. Alloys and Compounds, 482 (2009) 440.

6. N. A. Szreder, P. Kosiorek, J. Karczewski, M. Gazda and R. J. Barczyński, Procedia Engineering 98 ( 2014 ) 62.

7. Meenakshi Pant, D. K. Kanchan and Nirali Gondaliya, Materials Chemistry and Physics, 115 (2009) 98.

8. Al-Hajry, A. Al-Shahrani and M.M. El-Desoky, J. Mat. Chem. Phys., 95 (2006) 300.
9. N. F. Mott, J. Non-Cyst. Solids, 1, (1968), 1.

10. S. Muthupari, S. Lakshmi Raghavan and K. J. Rao, J. Phys. Chem., 100, (1996), 4243.

11. G. B. Devidas, T. Sankarappa, B. K. Chougule and G. Prasad, J. Non-Cyst Solids, 353 (2007) 426.

12. F. A. Moustaffa, A. A. Abd El-Mongy, A. M. Sanad, I. Kashif and A. G. Mostafa, J. Material Science Letters, 4 (1985) 1054.

13. A. M. Sanad, A. G. Mostafa, F. A. Mousttaffa and A. A. El-Mongy, Central Glass \& Ceramic Bulletin, 32 (3) (1985) 1.

14. A. G. Mostafa, Indian J. Phys., 62a (1988) 262.

15. M. S. Aziz, A. G. Mostafa, A. M. Youssef, H. Zidan and S. M. S. Youssif. Egyptian J. Solids, 33 (1) (2010)143.

16. A. G. Mostafa and M. A. Salem, Indian J. Phys. 61A (1987) 516.

17. H. A. Saudi, Applied Mathematics \& Physics, 1 (4) (2013)143.

18. A. M. Abdel Ghany, M. S. S. Saad, I. I. Bashter, T. Z. Amer, S. M. Salem and A. G. Mostafa, Nature \& Science, 12 (12) (2014) 162.

19. A. M. Abdel-Ghany, A. M. Zoulfakar, T. Z. Abou-Elnasr, M. Y. Hassaan and A. G. Mostafa, American J. Physics \& Applications, 3 (6) (2015) 208.

20. H. A. Saudi, A. G. Mostafa, N. Sheta, S. U. El Kameesy and H. A. Sallam, Physica B: Condensed Matter, 406 (21) (2011) 4001.

21. M. Shapaan, J. Non-Cryst. Solids, 356 (2010) 314.

22. Mohamed Gabr, Karam Abdel-Ati Ali \& A. G. Mostafa, Turk. J. Phys., 31 (2007) 31.

23. A. M. Zoulfakar, A. M. Abdel-Ghany, T. Z. Abou-Elnasr, A. G. Mostafa, S. M. Salem and H. H. El-Bahnaswy, Appl. Radi. Iso., 127 (2017) 269.

24. A. M. Abdel-Ghany, A. A. Bendary, T. Z. Abou-El-Nasr, M. Y. Hassaan and A. G. Mostafa, Nature and Science, 12(6) (2014)139.

25. A. Abd El-Mongy, Phys. Stat. Sol., (a) 136, (1994) 17.

26. F. A. Cotton and G. Wilkinson, Advanced Inorganic Chemistry", wiley Eastern, Private limited, New Delhy (1972).

27. F. Abdel-Wahab, A. G. Mostafa, A. E. Belal and E. M. El-Agwany, Materials Chemistry \& Physics, 93 (2005) 243. . 


\section{تأثير أيونات الهالوجين على الخواص الفيزيائية لبعض عينات من زجاج \\ البورو-فاناديوم. \\ احمد محمد احمد عبد الغنى \\ قسم العلوم الأساسية_ كلية العلوم الهندسيةـ جامعة سيناء_العريش_مصر}

الملخص العزبح:

تم تحضير عينات زجاجية من اكاسيد الصوديوم و البورون و الفاناديوم وتم اضافة أيونات الهالوجين المختلفة (الكلور ، البروم أو البود) تم صهر العيناتعند درجة حرارة . . . 1 درجة مئوية لمدة ساعتين. وقد تم قياس الكثافة، التوصيلية

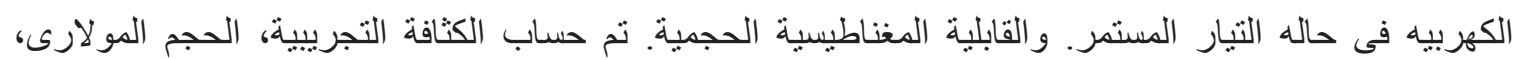

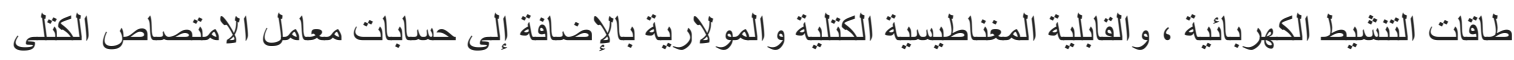
للعينات موضوع الدر اسة. وقد وجد انه باضافه ايونات الهالوجين للعينات على حساب اكسيد الصوديو حدث التالى: • لوحظ نقص الكثافه كما ان الكثافة عند اضافة الكلور اعلى من الكثافة عند اضافة الباريوم اعلى من الكثافه عند

اضافة اليود. الحجم المو لارى يقل و الحجم المولارى اكبر عند اضافة اليود عكس الكثافة. وجد أن طاقة التنشيط انخفضت مع زيادة ايونات الهالوجين و الذي قد يكون ناتجا عن الزيادة في حركة أيونات الصوديوم والتكوين التنريجي لبعض الهالوجينات غير الجسرية الطرفية ، بالإضافة إلى عملية الققز الإلكترون بين حالات الأكسدة المختلفة للفاناديوم.ايضا انخفاض طاقة التنشيط أيضا من الكلور إلى اليود التي يمكن بالئه إرجاعها إلى الاختلافات في الأقطار الأيونية من أيونات الهالوجين. أيضا ، قد برجع الانخفاض في طاقة التنشيط

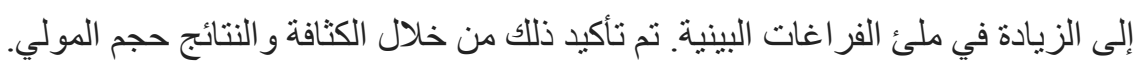

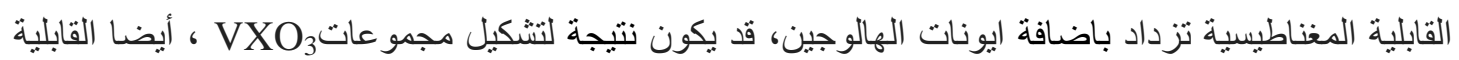
المغناطيسية تقل وذللك كلما زاد نصف قطر ايون الهالوجين المضاف للثبيكه. يمكن أن يعزى ذلك إلى الزيادة في الفر اغات البينية فى الثبيكة. وفقا لنتائج معاملات الامتصاص الكتلى لكل العينات، فقد وجد أن العينة تحتوي على ب مول مول NaI هى أفضل عينه يمكن استخدامه لامتصاص ray-ray، ولكن فقط في طاقات أشعقةمنخفضة مثل بـ ب كيلو الكترون فولت. 